\title{
Economic Analysis of Tribal Farm in Gadchiroli District of Maharashtra, India
}

\author{
D.U. Meshram*, S.S. More and R.D. Shelke \\ Department of Agricultural Economics, College of Agriculture, Latur, India \\ *Corresponding author
}

\section{A B S T R A C T}

\begin{tabular}{|c|}
\hline Keywords \\
\hline $\begin{array}{l}\text { Socio economic } \\
\text { status, Tribals, } \\
\text { Employment pattern }\end{array}$ \\
\hline Article Info \\
\hline $\begin{array}{l}\text { Accepted: } \\
15 \text { June } 2018 \\
\text { Available Online: } \\
10 \text { July } 2018\end{array}$ \\
\hline
\end{tabular}

\section{Introduction}

After sixty nine years of independence the development in economics, social, educational and political sectors generally visible, but the tribal community are far behind and unaware of these developments. The tribal communities are under the burden of poverty, illiteracy, superstition and various addictions. They are slaves of old traditions and customs and this is a great hurdle in the way of their development. They are even not able to express their pains, sorrows and also their identities, feelings etc., which are under a prolonged dormancy.

In order to get a clear view of these issues, this study attempts to examine the comparative

\begin{abstract}
An attempt has been made in the present investigation to study the employment, income and consumption pattern of tribals in Dhanora tahsil of Gadchiroli district. The study is ased on the primary data of 60 tribal households obtained from three villages belonging the tribal area of Dhanora tahsil drawn through simple randomization. The data for the method of analyst used is simple tabular method and regression technique. The study revealed that the tribal households had mostly the poor quality lands with no irrigation facilities. The agriculture was observed to be of subsistence in nature. Low standard of living, illiteracy, education up to primary level and low capital investment in productive assets of the sample tribal households have resulted into low level of socio economic conditions among the individuals or families of the tribal society, with less differences among the size classes and were below the state averages.
\end{abstract}

analysis of socio-economic conditions of tribal farmers in Gadchiroli district of Maharashtra. Gadchiroli is one of district of Maharashtra in India. There are 12 Talukas, 1,675 villages and 6 towns in Gadchiroli district. As per the Census India 2011, Gadchiroli district has 2, 50,435 households, population of $10,72,942$ of which 5, 41,328 are males and 5,31,614 are females. The population of children between age $0-6$ is $1,20,272$ which is $11.21 \%$ of total population. The sex-ratio of Gadchiroli district is around 982 compared to 929 which is average of Maharashtra state. The literacy rate of Gadchiroli district is $66.02 \%$ out of which $72.99 \%$ males are literate and $58.93 \%$ females are literate. The total area of Gadchiroli is 14,412 sq. $\mathrm{km}$ with population density of 
74 per sq.km. Out of total population, $89 \%$ of population lives in urban area and $11 \%$ lives in rural area. There are $11.25 \%$ Scheduled Caste (SC) and $38.71 \%$ Scheduled Tribe (ST) of total population in Gadchiroli district.

The main objectives includes, to examine the socio-economic status of farm and non-farm tribal families. And also to study the employment pattern of the farm and non-farm tribal families

\section{Materials and Methods}

On the basis of population of tribals, 1 tehsil (Dhanora) from Gadchiroli district was selected. On the basis of population of tribals, 3 villages (Chatgaon, Sawargaon and Tukum) from selected tehsil were selected for study. To study the different aspects of overall tribal economy, the sample tribal families were categorized into two groups i. e. farm tribals and non-farm tribals. From each village, 20 farmers (10 from farm tribals and 10 from non-farm tribals) were selected randomly. The study were required both primary as well as secondary data on different aspects of the tribal population in the district.

Socio economic status of farm tribals were calculated and are presented in table no.4.1 it was observed that at average age of farm tribals is 49.66 years in study area. It means middle age tribals are available in study area. As well as the non-farm age mean is 47.43 years. It was observed that at average education of farm tribals is 1.96 and non-farm is 1.76. It found that most of farm and nonfarm tribals are illiterate in study area. It was observed that at average family size of tribal farm is 4.6 and non-farm is clear that most of the family have 4 to 6 members in their family in study area. It was observed that at average land holding of tribal farm is 2.24 ha. It's clear in the study area the average land holding is 2 ha. It was observed that at average number of animals of tribal farm are 4.03 and non-farm is 18.96. It found that the number of animals is in the study area farm tribals is 2 to 4 animal and non-farm tribals have more than farm tribals in each farmers. It was observed that at average total income of tribal farm is 199103.33 and non-farm is 88078.66 . It shows the total income of farm tribals is greater than the non-farm tribals.

\section{Results and Discussion}

Farm tribals were calculated and are presented in table no.4.2 Total land is 67.31 ha. And gross cropped area is 73.25 ha likewise net sown area is 67.25 ha and its mean is 2.24, 2.44 and 2.24 respectively.

Farm tribals were calculated and are presented in table no.4.3. Here calculated the cropping intensity and it obtained 108.24.

Farm tribals were calculated and are presented in table no.4.4. In this table we found that the position and value of asset which is used by farmers. So here building purchase value mean is 73966.66 Rs. and Present Value is 151666.66 Rs. as well as farm machinery purchase value is $3814.28 \mathrm{Rs}$. and present value is 7242.85 Rs. Farm Implements purchase value is Rs. 3488.33 and present value is Rs. 5849.33 Tools purchase value is Rs.399.66 and present value is Rs. 515.5 and last Others purchase value is 16455.33 and present value 27871.Its clear that the purchase price is smaller than present price value.

Non-farm tribals were calculated and are presented in table no.4.4. In this table we found that the position and value of asset which is used by farmers. So here building purchase value mean is Rs. 43233.33 and Present Value is Rs. 80683.33. Farm Implements purchase value is Rs. 610 and present value is Rs. 940. Tools purchase value is Rs.470.83 and present value is Rs. 570.66 
and last others purchase value is Rs. 12086.66 and present value is Rs. 14793.33. It's clear that the purchase price is smaller than present price value. Table no. 4.4 showed the purchase value and present value of assets farm tribals is greater than non-farm tribals.

Farm tribals under the livestock position and its value showed in table no. 4.5 and it calculated which obtained draft animals total number mean is 1.5 and its value is 1500.Milch animal's total number mean is 1.42 and its value is12500. Dry animal total number mean is 0 and its value also 0 . Calves total number mean is 9 and its value is 2744.44.

Table no.4.5 showed that the farm and nonfarm tribals livestock total numbers and its value. The result is found that the farm tribals have draft animals more and non-farm tribals have calves which is below 1 year and it included poultry, goat etc. Non-farm tribals under the livestock position and its value showed in table no. 4.6 and it calculated which obtained draft animals total number mean is 0.06 and its value is 666.66. Milch animal's total number mean is 0.06 and its value is666.66. Calves total number mean is 20.17 and its value is 13564.13.

The net worthy information on the cropping pattern adopted by the sample tribal farm is given in table no. 4.6

It can be seen from the table that, the cereals are important crops and occupied about 82.52 per cent of the total cropped area during 20172018 in study area. Amongst the different cereals, occupied 60.45 per cent area, whereas, pulses occupied about 17.47 per cent for both kharif and rabi. The other important crops of the district are wheat and paddy. Paddy occupied 74.33 per cent, wheat occupied 8.19 per cent. The total average of Rice is 1.815 in study area.

The total average of Wheat is 0.2 in study area. The total average of Red gram is 17.47 in study area. It observed that in presented in table no.4.6 the Rice is used most in study area as compare to other crops. After the Rice second rank is Red gram crop. And in little range wheat crop is taken in study area. Results revealed that majority of the farmers had adopted the rice production technology.

Table no.4.7 presents the employment pattern of farm and non-farm tribals. In this table it is clear that the working member of farm and non-farm tribals is same. And male worker of farm tribals is greater than non-farm tribals and female worker of farm tribals is smaller than non-farm tribals as well as children worker of farm tribals is smaller than nonfarm tribals after that crop production employment mean is in farm tribals is more than non-farm tribals. Livestock employment is only to farm tribals. And the main point is egs/manrega or any govt. scheme work is get more to non-farm tribals as compare to farm tribals. Also business or any service employment is more to non-farm tribals.

Table.1 Land utilization of farm tribals

\begin{tabular}{|c|c|c|c|}
\hline Sr. No. & Particulars & Total (Ha) & Mean \\
\hline $\mathbf{1 .}$ & Total land & 67.31 & 2.24 \\
\hline $\mathbf{2}$ & Gross cropped area (ha) & 73.25 & 2.44 \\
\hline $\mathbf{3}$ & Net sown area (a) & 67.25 & 2.24 \\
\hline
\end{tabular}


Table.2 Socio-economic status of farm and non-farm tribals

\begin{tabular}{|c|l|c|c|}
\hline Sr. No. & Particular & \multicolumn{2}{|c|}{ Mean } \\
\hline $\mathbf{1}$ & Age & 49.66 & Non-farm \\
\hline $\mathbf{2}$ & Education & 1.96 & 47.43 \\
\hline $\mathbf{3}$ & Family size & 4.6 & 1.76 \\
\hline $\mathbf{4}$ & Male & 1.93 & 5.16 \\
\hline $\mathbf{5}$ & Female & 1.43 & 2.6 \\
\hline $\mathbf{6}$ & Children & 1.23 & 1.76 \\
\hline $\mathbf{7}$ & Land holding & 2.24 & 0.8 \\
\hline $\mathbf{8}$ & No. of animal & 4.03 & - \\
\hline $\mathbf{9}$ & Total income & 199103.33 & 88078.66 \\
\hline
\end{tabular}

Table.3 Cropping intensity of farm tribals

\begin{tabular}{|c|l|l|l|}
\hline Sr. No. & Particulars & Total & Mean \\
\hline $\mathbf{1}$ & Net sown area (ha) & 67.25 & 2.24 \\
\hline $\mathbf{2}$ & Gross cropped area (ha) & 73.25 & 2.44 \\
\hline $\mathbf{3}$ & Cropping Intensity & 108.92 & 108.92 \\
\hline
\end{tabular}


Table.4 Asset position of farm and non-farm tribals

\begin{tabular}{|c|c|c|c|c|c|c|c|c|c|}
\hline \multirow[t]{3}{*}{ Sr. No. } & \multirow[t]{3}{*}{ Particulars } & \multicolumn{4}{|c|}{ Farm } & \multicolumn{4}{|c|}{ Non-farm } \\
\hline & & \multicolumn{2}{|c|}{ Purchase value } & \multicolumn{2}{|c|}{ Present Value } & \multicolumn{2}{|c|}{ Purchase Value } & \multicolumn{2}{|c|}{ Present Value } \\
\hline & & Total & Mean & Total & Mean & Total & Mean & Total & Mean \\
\hline 1 & Building & 2219000 & 73966.66 & 4550000 & 151666.66 & 1297000 & 43233.33 & 2420500 & 80683.33 \\
\hline 2 & $\begin{array}{l}\text { Farm } \\
\text { Machinery }\end{array}$ & 26700 & 3814.28 & 50700 & 7242.85 & 0 & 0 & 0 & 0 \\
\hline 3 & $\begin{array}{l}\text { Farm } \\
\text { Implements }\end{array}$ & 104650 & 3488.33 & 175480 & 5849.33 & 18300 & 610 & 28200 & 940 \\
\hline 4 & Tools & 11990 & 399.66 & 15465 & 515.5 & 14125 & 470.83 & 17120 & 570.66 \\
\hline 5 & Others & 493660 & 16455.33 & 836130 & 27871 & 362600 & 12086.66 & 443800 & 14793.33 \\
\hline
\end{tabular}

Table.5 Livestock position and value of farm and non-farm tribals

\begin{tabular}{|c|l|c|c|c|c|c|c|c|c|}
\hline Sr. No. & Particulars & \multicolumn{3}{|c|}{} & \multicolumn{3}{|c|}{ Farm } & \multicolumn{3}{|c|}{ Non-farm } \\
\hline & & $\begin{array}{c}\text { Total } \\
\text { No. }\end{array}$ & Mean & $\begin{array}{c}\text { Total } \\
\text { value }\end{array}$ & Mean & $\begin{array}{c}\text { Total } \\
\text { No. }\end{array}$ & Mean & $\begin{array}{c}\text { Total } \\
\text { value }\end{array}$ & Mean \\
\hline $\mathbf{1}$ & Draft animals & 30 & 1.5 & 300000 & 15000 & 2 & 0.06 & 20000 & 666.66 \\
\hline $\mathbf{2}$ & $\begin{array}{l}\text { Milch } \\
\text { Animals }\end{array}$ & 10 & 1.42 & 100000 & 12500 & 2 & 0.06 & 20000 & 666.66 \\
\hline $\mathbf{3}$ & $\begin{array}{l}\text { Dry animals } \\
\mathbf{4}\end{array}$ & 0 & 0 & 0 & 0 & 0 & 0 & 0 & 0 \\
\hline
\end{tabular}


Table.6 Cropping pattern of tribal farmers

\begin{tabular}{|c|l|c|c|c|}
\hline Sr. No & Crop & Total Area (Ha) & Mean & $\begin{array}{c}\text { Percentage to the total } \\
(2017-18)\end{array}$ \\
\hline $\mathbf{1}$ & Rice & 54.45 & 1.815 & 74.33 \\
\hline $\mathbf{2}$ & Wheat & 6 & 0.2 & 8.19 \\
\hline $\mathbf{3}$ & Total Cereals & 60.45 & 2.015 & 82.52 \\
\hline $\mathbf{4}$ & Red Gram & 12.8 & 0.42 & 17.47 \\
\hline $\mathbf{5}$ & Total Pulses & 12.8 & 0.42 & 17.47 \\
\hline $\mathbf{6}$ & Gross cropped area & 73.25 & 2.44 & - \\
\hline $\mathbf{7}$ & Oilseeds & 00 & 00 & 00 \\
\hline
\end{tabular}

Table.7 Employment pattern of farm and non-farm tribal

\begin{tabular}{|c|c|c|c|}
\hline Sr. No. & Particulars & \multicolumn{2}{|c|}{ Mean } \\
\hline & & Farm & Non-farm \\
\hline $\mathbf{1}$ & Working member & 3.63 & 3.63 \\
\hline $\mathbf{A}$ & Male & 2 & 1.83 \\
\hline $\mathbf{B}$ & Female & 1.4 & 1.53 \\
\hline $\mathbf{C}$ & Children & 0.1 & 0.13 \\
\hline $\mathbf{2}$ & Crop production & 17775 & 14580 \\
\hline $\mathbf{3}$ & Livestock & 266.66 & 0 \\
\hline $\mathbf{4}$ & Egs/manrega & 11436.66 & 13130 \\
\hline $\mathbf{5}$ & Business /service & 1443.33 & 75310.34 \\
\hline
\end{tabular}


In conclusion, low standard of living, illiteracy and education upto primary level, low capital investment in productive asset was seen amongst the tribal families. The tribals households had mostly the poor quality lands and absence of poor quality facilities. The cropping pattern was predominant with food grain crops indicating subsistent agriculture.

\section{References}

Arook T. and R. Rahanman, 2016. Socioeconomic condition of plan land tribal people in Bangladesh. Social Sciences, 5(4): 58-63.

Chakaravarti I. and S. Sethia, 1991. Exploitative employment and income of tribal Agricultural labour in Udaipur district of Rajasthan, Research University of Agri. Sciences. 20(12):262-362.

Devi, S. A., 2005. Socio-Economic Conditions of Tribes. Sonali Publications, New Delhi.

Hossain, D.M., 2013. Socio-economic Condition of the Indigenous People in the Chittagong Hill Tracts (CHT) of Bangladesh, Middle East Journal of Business, 8 (2):22-30.

Mishra, C.S., 2007. Impact of tribal development on employment income and assets formation in Bastar district of Madhya Pradesh. Journal Indian of Agricultural Economic, 25(4): 135136.

\section{How to cite this article:}

Meshram, D.U., S.S. More and Shelke, R.D. 2018. Economic Analysis of Tribal Farm in Gadchiroli District of Maharashtra Int.J.Curr.Microbiol.App.Sci. 7(07): 2099-2105. doi: https://doi.org/10.20546/ijcmas.2018.707.247 